\title{
COMBINED LIVER-KIDNEY TRANSPLANTATION: EXPERIENCE AT A BRAZILIAN UNIVERSITY HOSPITAL
}

\author{
Transplante combinado fígado-rim: experiência de um hospital universitário brasileiro
}

Francisca Jovita de Oliveira VERAS, Gustavo Rêgo COELHO, Bartolomeu Alves FEITOSA-NETO,
João Batista Gadelha CERQUEIRA, Regina Célia F. Gomes GARCIA, José Huygens Parente GARCIA

From the Departamento de Cirurgia, Universidade Federal do Ceará (Department of Surgery, Federal University of Ceará), Fortaleza, CE, Brazil.

HEADINGS - Kidney transplantation. Liver transplantation. Survival.
ABSTRACT - Background: Combined liver-kidney transplant is a routine procedure in many transplant centers. The increase in its number coincided with the introduction in 2002 of the MELD (Model for End-stage Liver Disease) score for allocation of livers, prioritizing patients with renal dysfunction. Aim: To analyze the experience with combined liver-kidney transplantation in a liver transplant center in Brazil. Method: A retrospective review was conducted. All transplants were performed using grafts from deceased donors. Results: Sixteen combined liver-kidney transplantations were performed in the same period, which corresponds to $2.7 \%$ and $2.5 \%$ of the kidney and liver transplants, respectively. Fourteen patients were male (87.5\%) and two were female (12.5\%). The average patients and donors age was $57.3 \pm 9.1$ and $32.7 \pm 13.1$, respectively. The MELD score mean was $23.6 \pm 3.67$. The main cause of liver dysfunction were chronic hepatitis $C$ virus $(n=9)$. As for renal dysfunction, diabetic nephropathy $(n=4)$ was the most frequent. There were six deaths, two of them by severe dysfunction of the liver graft and four by infectious causes. The 1,3 and 5 years survival rate in patients undergoing liver-kidney transplantations was $68.8 \%, 57.3 \%$ and $57.3 \%$, respectively. Conclusion: The survival rates achieved in this series are considered satisfactory and show that this procedure has an acceptable morbidity and survival.

\section{Correspondence: \\ Francisca Jovita de Oliveira Veras \\ E-mail: jovitaveras@gmail.com \\ Financial source: none \\ Conflicts of interest: none}

Received for publication: 15/08/2013

Accepted for publication: 12/12/2013

DESCRTORES - Transplante renal. Transplante hepático. Sobrevida.
RESUMO - Racional: O transplante combinado fígado-rim é procedimento de rotina em muitos centros de transplante. O aumento no seu número coincidiu com a introdução em 2002 do escore MELD (Model for End-stage Liver Disease) para alocar fígados, priorizando pacientes com disfunção renal. Objetivo: Mostrar a experiência em transplante combinado fígado-rim de um centro de transplante hepático. Método: Foi realizado estudo retrospectivo de pacientes adultos tratados com transplante combinado fígado-rim. Todos foram feitos com enxertos de doadores cadáveres. Resultados: Dezesseis transplantes combinados fígado-rim foram realizados no período, correspondendo a 2,7\% e 2,5\% dos transplantes de rim e fígado, respectivamente. Quatorze eram homens (87,5\%) e duas mulheres (12,5\%). A média

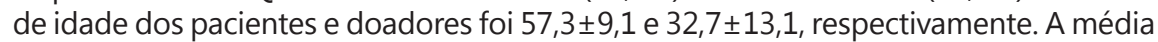

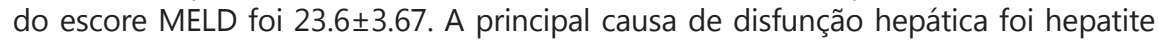
crônica pelo vírus $C(n=9)$. Para a disfunção renal, nefropatia diabética $(n=4)$ foi a mais frequente. Houve seis mortes, duas por disfunção grave do enxerto hepático e quatro por causas infecciosas. A taxa de sobrevida dos pacientes submetidos ao transplante combinado fígado-rim no $1^{\circ}, 3^{\circ}$ e $5^{\circ}$ anos foi $68.8 \%, 57.3 \%$ e $57.3 \%$, respectivamente. Conclusão: As taxas de sobrevida alcançadas nesta série são consideradas satisfatórias e mostram que este procedimento tem morbidade e sobrevida aceitáveis.

\section{INTRODUCTION}

$\mathrm{T}$ he first combined liver-kidney transplant (CLKT) was performed in 1983 by Margreiter ${ }^{10}$, and it is a routine procedure in many transplant centers representing 1-8\% of liver transplant candidates ${ }^{3}$. The increase in double transplantation coincided with the introduction in 2002 of the MELD score for allocation of livers, due to the heavily weighted serum creatinine value in its calculation, prioritizing patients with renal dysfunction. As a result there has been considerable increase in number of CLKT in the past few years ${ }^{2,5}$. 
Regarding graft survival it seems that the liver graft has an immune protective effect on kidney graft when both organs came from the same donor ${ }^{5,9}$ and studies indicate that there is a greater survival in dialysis-dependent patients with renal dysfunction undergoing double transplantation when compared with those who perform liver transplant alone ${ }^{6}$. Also renal dysfunction before and after liver transplant is the greatest determination of mortality ${ }^{4}$.

The most frequent indications for liver transplantation in Brazil is in relation to the hepatitis $C$ virus-induced cirrhosis and alcohol-induced cirrhosis. Concerning the etiology of kidney failure, the main indications for renal replacement are diabetic nephropathy and chronic glomerular disease.

The aim of this article is to analyze the experience with CLKT in a liver transplant enter in Northeastern Brazil.

\section{METHODS}

A retrospective analysis was conducted on basis of selected adult patients treated between May 2002 and June 2012 with CLKT at Walter Cantídio University Hospital of the Federal University of Ceará, Brazil.

Were analyzed gender, age, MELD score at the operation, liver cold and warm ischemic times, the causes of dysfunction, mortality, follow-up in five years and the length of hospital stay. All transplants were performed using grafts from deceased donors and piggyback approach. After completion of liver transplantation, the kidney graft was implanted retroperitoneally through Gibson incision. Immunosuppressive therapy consisted of tacrolimus and prednisone in all patients.

The survival rates achieved in this series were statisticaly analysed using SPSS version 17.0 software (SPSS Inc, Chicago, III,USA). Data were expressed as mean values standard deviation (SD). Actuarial survival curves were calculated using Kaplan-Meier method.

\section{RESULTS}

In the period, were performed 616 kidney transplants and 674 liver transplants. Sixteen CLKT were done in the same period, which corresponds to $2.7 \%$ and $2.5 \%$ of the kidney and liver transplantation. Fourteen patients were male $(87.5 \%)$ and two were female (12.5\%). The average patients and donors age was $57.3 \pm 9.1$ and $32.7 \pm 13.1$, respectively. The MELD (Model for End-stage Liver Disease) score mean was $23.6 \pm 3.67$ (range 20-35). Causes of liver dysfunction were chronic hepatitis $C$ virus $(n=9)$, alcohol $(n=4)$, cryptogenic $(n=2)$ and polycystic liver disease $(n=1)$. As for renal dysfunction, diabetic nephropathy $(n=4)$, hypertensive nephropathy $(n=2)$, an association between diabetic and hypertensive nephrosclerosis $(n=2)$, lupus nephritis $(n=1)$, polycystic kidney disease $(n=2)$, nonspecific glomerulonephritis $(n=2)$, and renal failure of unknown etiology $(n=3)$. The mean liver cold and warm ischemic time was $310.6 \pm 75.7$ and $29.2 \pm 7.9$ minutes, respectively. The average length of hospital stay was $34 \pm 18$ days (Table 1 ).

TABLE 1 - General CLKT parameters

\begin{tabular}{|l|c|}
\hline Parameters & Mean \\
\hline Recipient age (yr) & $57.3 \pm 9.1$ \\
\hline Donor age (yr) & $32.7 \pm 13.1$ \\
\hline MELD & $23.6 \pm 3.67$ \\
\hline Liver cold ischemic time (min) & $310.6 \pm 75.7$ \\
\hline Liver warm ischemic time (min) & $29.2 \pm 7.9$ \\
\hline Hospital stay (days) & $34.0 \pm 18.0$ \\
\hline
\end{tabular}

Surgical complications occurred in two patients; one had biliary fistula and the other urinary fistula, both treated conservatively. Two patients had recurrence of hepatitis $C$ virus. In two cases was observed acute renal allograft dysfunction. Postoperative dialysis was required in only two patients. There were six deaths, two of them by severe dysfunction of the liver graft and four by infectious causes. The one, three and five years survival rate in patients undergoing CLKT was $68.8 \%$, $57.3 \%$ and $57.3 \%$, respectively (Figure 1 ).

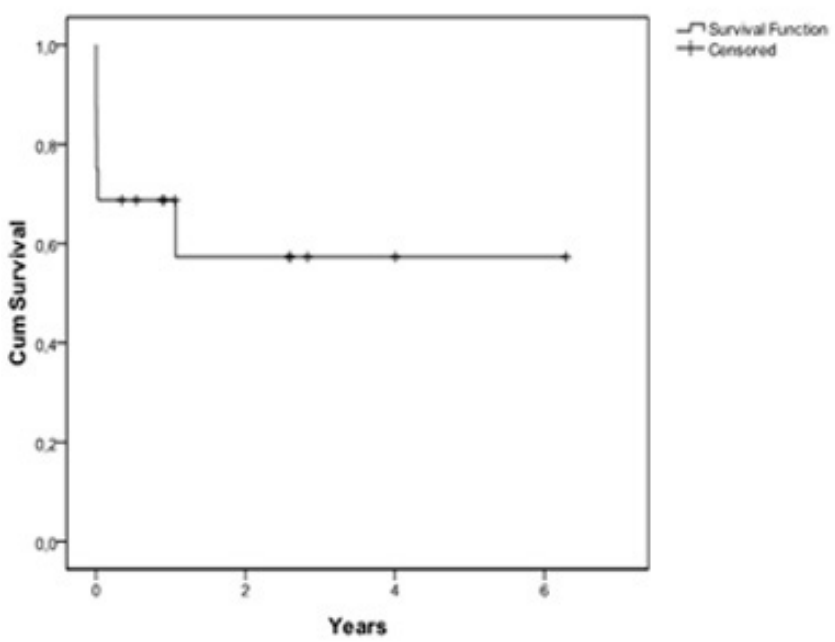

FIGURE 1 - Overall patients survival

\section{DISCUSSION}

After 10 years of establishment of the Liver Transplantation Program at Walter Cantídio University Hospital of the Federal University of Ceará, this is the first CLKT series from liver transplantation program, published in the international literature. The survival rates achieved are considered satisfactory when compared to data published by the most important transplant centers in USA and Europe ${ }^{7}$ and it shows that this procedure has an acceptable morbidity and survival. Recognition of negative effects of renal failure associated with end-stage liver disease in outcome 
of liver transplant ${ }^{1}$ encourages transplantation teams to perform the CLKT, seeking improvement in patients survival. It is known that this choice should be meticulous, since the gains in survival of patients undergoing CLKT are observed in patients with severe renal disease (dialysis-dependent for $>3$ months) ${ }^{8}$.

\section{CONCLUSION}

The survival rates achieved in this series are considered satisfactory and show that this procedure has an acceptable morbidity and survival.

\section{REFERENCES}

1. Margreiter R, Kramar R, Huber C, Steiner E, Niederwieser D, Judmaier $\mathrm{G}$, et al. Combined liver and Kidney transplantation. The Lancet 1984;1:1077-8.

2. Davis $\mathrm{CL}$, Gonwa $\mathrm{TA}$, Wilkinson $\mathrm{AH}$. Identification of patients best suited for combined liver-kidney transplantation: part II. Liver transpl. 2002;8:193-211.
3. Davis $C L$, Feng $S$, Sung $R$, et al. Simultaneos liver-Kidney transplantation: evaluation to decision making. Am J Transplant. 2007;7:1702-9.

4. Fagundes C, Guevara M. Combined liver and kidney transplantation. In: Ortiz J. Understanding the Complexities of kidney transplantation. Intech, Sept 2011.

5. Margreiter R, Konigsrainer A, et al. Our Experience with combined liver-kidney transplantation: an update. Transplant Proc. 2002; 34:2491-2492.

6. Gonwa TA, McBride MA, Anderson K, Mai ML, Wadei H, Ahsan N. Continued influence of preoperative renal function on outcome of orthotopic liver transplant (OLTX) in the US: where will MELD lead? Am J Transplant. 2006;6:2651-9.

7. Eason JD, Gonwa TA, Davis CL, et al. Proceedings of Consensus Conference on Simultaneous Liver Kidney Transplantation (SLK). Am J Transplant. 2008;8:2243-2251.

8. Hibi T, Sageshima J, Molina E, Ciancio G, Nishida S, Chen L, at al. Predisposing Factors of Diminished Survival in Simultaneous Liver/ Kidney Transplantation. Am J Transplant. 2012;12: 2966-2973.

9. Bahirwani R, Reddy KR. Outcomes after liver transplantation: chronic kidney disease. Liver Transpl. 2009;15 Suppl 2:S70-74.

10. Locke JE, Warren DS, Singer AL, Singer AL, Segev DL, Simpkins $C E$, et al. Declining outcomes in simultaneous liver-kidney transplantation in the MELD era: ineffective usage of renal allografts. Transplantation. 2008;85:935-942. 